\title{
İşin Anlamlılı̆̆ının Sapma Davranışı ve Performansa Etkisi
}

\author{
The Effect of Meaning of Work on Workplace Deviance Behavior and Job \\ Performance
}

\author{
Ceren EVCIMEN* \\ Ayșehan ÇAKICI** \\ Celil ÇAKICI***
}

\begin{abstract}
$\ddot{O} Z$
İs, bireylerin günlük yaşamının önemli bir parçasıdır. İşe; psikolojik, sosyolojik ve ekonomik açıdan çeşitli anlamlar yüklenebilmektedir. Bu kapsamda; işin anlamlllĭgının örgütsel sapma ve iş performansina etkisini ortaya koymak üzere bir araştırma yapılmıştır. Veriler, literatürden yararlanılarak geliştirilen bir anket ile toplanmııştır. Anket; aktif iş yaşamında olan bireylere, 2016 yllının Mayls-Haziran aylarında kolayda örnekleme tekniği ile uygulanmuştır. Veriler, tanımlayıcı istatistiklerin yanı sıra, açıklayıcı ve doğrulayıcı faktör analizi ve yapısal modellemesi yoluyla analiz edilmiștir. İșin anlamlıllğının iş performansinı olumlu yönde etkilediği belirlenirken, üretime dönük ve kişilerarası sapma davranışını olumsuz yönde etkilediği tespit edilmiştir. Kişilerarası sapma davranışıııı iş performansı üzerinde anlamlı bir etkisi yok iken, üretime dönük sapma davranışının iş performansını düşürdüğ̈̈ ortaya çıkmıştır. Çalışma; çalışanların iş anlamlıllı̆̆ algısını geliştirecek liderlik uygulamalarında bulunulması ve işyerindeki sapma davranışına karşı dikkatli olunması önerisi ile son bulmaktadır.
\end{abstract}

\section{ANAHTAR KELIMELER}

İşin Anlamlllı̆̆l, Sapma Davranışı, Üretime Dönük Sapma Davranış̧ı, Kişsilerarası Sapma Davranışı, İş Performansı

\begin{abstract}
Work is an important part of individuals' daily life. Psychological, sociological and economic meanings might be attributed to job. In this context; a research was conducted to reveal the effect of the meaning of work on organizational deviation and job performance. The data were collected via a questionnaire developed based on the literature. The questionnaire was applied to individuals in active business life with convenience sampling technique in May-June 2016. The data were analyzed through descriptive statistics, as well as explanatory and confirmatory factor analysis and structural equation modeling. It had been determined that the meaning of work positively affected the job performance, while it had a negative effect on the production-oriented and interpersonal deviation behavior. While interpersonal deviation behavior had no significant effect on job performance, it has been revealed that production-oriented deviation behavior had reduced the job performance. Study ends with the suggestion of taking leadership practices improving employees' perception of meaning of work and being careful against workplace deviation behavior.
\end{abstract}

\section{KEYWORDS}

Meaning of Work, Workplace Deviance Behavior, Production-Oriented Deviance Behavior, Interpersonal Deviance Behavior, Job Performance

\begin{tabular}{|c|c|c|}
\hline \multicolumn{2}{|r|}{$\begin{array}{c}\text { Makale Geliş Tarihi / Submission Date } \\
21.08 .2020\end{array}$} & $\begin{array}{c}\text { Makale Kabul Tarihi / Date of Acceptance } \\
13.11 .2020\end{array}$ \\
\hline Atuf & $\begin{array}{l}\text { Evcimen, C., Çakıcı, A. ve Çakıcı, C } \\
\text { Üniversitesi Sosyal Bilimler Meslek Yı }\end{array}$ & $\begin{array}{l}\text { ğının Sapma Davranışı ve Performansa Etkisi. Selçuk } \\
\text { 2), 672-683. }\end{array}$ \\
\hline
\end{tabular}

\footnotetext{
* Dr., Mersin Üniversitesi, cerenevcimen0@ gmail.com, ORCID: 0000-0002-7915-2984

** Prof. Dr., Mersin Üniversitesi, İktisadi ve İdari Bilimler Fakültesi, aysehancakici@mersin.edu.tr, ORCID: 0000-0003-4090-5309

${ }^{* * *}$ Prof. Dr., Mersin Üniversitesi, Turizm Fakültesi, celilcakici@ mersin.edu.tr, ORCID: 0000-0002-9192-1969
} 


\section{GİRIŞ}

İşin, modern yaşamın önemli bir parçası olduğu (Baumeister, 1991: 116; Brown, 1996: 235; Wrzesniewski, 2003: 297) ve bireylerin zamanlarının büyük kısmını geçirdikleri bu faaliyete pek çok anlam yükledikleri vurgulanmaktadır (Baumeister, 1991: 116; Dik vd., 2009: 628). İnsanların işlerinin bir maaş elde etmekten ya da vakitlerini geçirmekten daha fazla bir şey ifade etmesini istediklerinden ve işlerinde harcadıkları zamanla her zamankinden çok daha fazla ilgilendiklerinden söz edilmektedir (Steger vd., 2012: 322). Bu bağlamda işin bireyler için taşıdığı anlamı tam olarak bilmeden ve hesaba katmadan yaşamın anlamına dair konuşmanın eksik kalacağ1 vurgulanmaktadır (Baumeister, 1991: 118). Her bireyin yaptığ 1 işte daha derin bir amaç ve anlam bulma çabası olduğu (Wrzesniewski, 2003: 298) ve paranın güdüleyici olma gücünü kaybettiği ifade edilmektedir (Seligman, 2002: 165). Bu bağlamda çalışanın performansını arttırmak için farklı unsurlara dikkat etmek gerektiği ortaya çıkmaktadır.

Performansın, örgütler için en önemli çıktılardan biri olduğu kuşkusuzdur. Örgütsel performansın tabandan tavana yayılan bir yapı gösterdiğine yönelik perspektif dikkate alındığında, bireysel performansın öne çıktığı düşünülebilir. $\mathrm{Bu}$ doğrultuda bireylerin çalışma güdülerinin nasıl geliştiğini ve işe yükledikleri anlamı düşünmek önem kazanmaktadır. Bazı bireyler sadece maddi ihtiyaçları, bazıları gelecek kaygıları, bazıları ise sadece işinden zevk aldığı için çalışmaktadır. Özetle çalışma motivasyonunun ve iş ortamındaki amaçların belirleyicileri, bireye özgü bir yapı göstermektedir (Barutçugil, 2002: 42). Dolayısıyla performansı arttıracak tek bir stratejinin varlığından söz etmek mümkün değildir.

Örgütlerin temel başarı ölçütü olarak görülen performans, örgüt hedeflerinin gerçekleşmesine katk1 sağlayan ve bireyin kontrolü altında olan her türlü davranış olarak tanımlanabilmektedir (Rotundo ve Sackett, 2002: 66). İş performansı yazını bu bağlamda değerlendirildiğinde vurgulanan üç temel iş davranış1 olduğundan söz etmek mümkündür. Dunlop ve Lee'ye göre (2004: 67-68) bunlar görev performans1, örgütsel vatandaşlık davranışı ve örgütsel sapma davranışı olarak ele alınmaktadır. Yazarlar, görev performansının yazında daha çok yer bulduğunu, hatta genel performans ile eşanlamlı ele alındığını, ancak genel performansın, görev performansı kadar görevle ilgili olmayan performansla da ilişkili olduğunu ileri sürmektedirler. Bu bağlamda örgütsel vatandaşlık davranışının yazında az da olsa yer bulduğu ancak iş performansı ile örgütsel sapma davranışı ilişkisini tartışan çalışmaların yok denecek kadar az olduğu ifade edilmektedir.

İşyeri hem fiziksel (para vb.) hem psikolojik (itibar vb.) gereksinimlerin karşılandığı bir çevre olduğundan güçlü duyguları tetikleyebilmektedir. Bu duygular, negatif durumları azaltıp pozitif olanları arttırmak üzere, eylem eğilimi ya da niyeti oluşturmaktadır. Negatif bir duyguyu tetikleyen durumlarda, aktif ve direkt olarak durumun öznesine saldırı (korkutma, tehdit) ya da pasif ve dolaylı olarak duyguyla baş etme (işten kaytarma, alkol kullanma, talimatlara uymama) gibi sapma davranışlarıdır (Spector ve Fox, 2002: 274). İşyerindeki durumunu elverişsiz olarak algılayan bireyler, örgüt normlarına zarar verebilir ve sapma davranış1 gösterebilirler (Colbert vd, 2004, s. 600). Bu kapsamda, işin anlamlılı̆̆ının çalışanın iş performansını ve sapma davranışını etkileme ve sapma davranışının da iş performansını etkileme potansiyelinde olduğu açıtıtır. Çalışma bu etkileşimleri tespit etmek amacıyla yapılmıştır. Çalışmanın, işin anlamlılığ ile ilgili çalışmalara yön gösterebileceği ve iş-işgören uyumunu sağlama konusunda uygulamacıların gereken özeni göstermelerine de katkı sağlayacağı düşünülmektedir. Sapma davranışı ile iş performansı ilişkisi, uygulamacıların dikkatini sapma davranışlarının oluşma koşullarına çekmesi açısından önemlidir.

\section{KAVRAMSAL ÇERÇEVE VE ILGILİ LITERATÜR}

\section{1. İşin Anlamlılığı}

İşin anlamlılı̆̆ı, bireyin iş deneyimine dair sübjektif ve pozitif algıları olarak tanımlanmaktadır. Kavram olarak da bireysel deneyim, biliş ve duygulara atıf yapmaktadır (Rosso vd, 2010: 94). İşin anlamlılığı, tutku ve ruhsallık boyutlarını içeren bir kavram olarak da görülmektedir (Steger vd., 2012: 325).

İşin anlamlılığının iş motivasyonu, devamsızlık, iş davranışı, tutkunluk, iş tatmini, güçlendirme, stres, örgütsel özdeşleşme, kariyer gelişimi, bireysel performans ve kendini gerçekleştirme gibi örgütsel çalışmaların en önemli çıktıları üzerinde etkili olduğu vurgulanmaktadır (Rosso vd, 2010: 92). Dolayısıyla işin anlamlılığı birçok değişkenle kolaylıkla ilişkilendirilebilmektedir.

İşin anlamlılığını başkaca kavramlarla ilişkilendirmeden irdeleyen çalışmalar olmakla birlikte (Demirtaş vd., 2015), psikolojik güçlendirmenin alt boyutu olarak da ele alınan çalışmalar (Ceylan vd., 2005: 48) söz konusudur. Ayrıca psikolojik güçlendirme-örgütsel vatandaşlık ilişkisinde de tartışlan (Arslantaş, 2008; Çöl, 2008; Hemedoğlu vd., 2012; Bal Taştan, 2013; Akgündüz vd., 2014; Bardakçığlu ve Akgündüz, 2016) bir kavram olmuştur. 
İşin anlamlılı̆̆ının üç temel boyutu olduğu belirtilmektedir (Steger vd., 2012: 324-325). Bu boyutlardan biri olan, "İşin pozitif anlamı"; sübjektif deneyimlere yani bireyin işini önemli ve anlamlı olarak değerlendirmesine işaret eder. Bir diğeri, "İșten anlam yaratma"; bireye kendine ve dünyaya dair derin bir anlayış sağlayarak kişisel gelişim imkânı verir. Son olarak, "çoğunluğun iyiliğii" boyutu ise, işin diğerleri üzerindeki etkisi arttıkça daha anlamlı hale geldiği fikrini ileri sürer.

\section{2. İş Performansı}

İş performansı, bireyin kontrolü altında bulunan ve örgütün hedeflerini gerçekleştirmesine olumlu katk1 sağlayan her türlü faaliyet ve davranışlardır (Rotundo ve Sackett, 2002: 66). İş performansı örgütler ve yöneticiler için temel olgulardan biri olup; rekabet gücü kazanmanın ancak yüksek performanslı çalışanlara sahip olmakla gerçekleşebileceği (Yelboğa, 2006: 200; Çalışkan ve Akkoç, 2012: 5), aksi durumda örgütün varlığını devam ettirme koşullarının riske gireceği (Özmutaf, 2007: 42) belirtilmektedir. Dolayısıyla iş performansının, örgütün rekabet gücüne işaret ettiğinin (Wang ve Netemeyer, 2002) ve örgütün etkililiği ve başarısı için temel faktör olduğunun (Suliman, 2001: 1049) altı çizilmektedir. Ayrıca görevini gereği gibi yapmanın ve yüksek başarı göstermenin bireyler için gurur ve tatmin kaynağı olduğu ve bireye sosyal anlamda da kariyer ve itibar gibi kazanımlar sağladığı ifade edilmektedir (Sonnetag ve Freese, 2002: 4).

İş performansı değişkeni alanyazında pek çok değişkenle birlikte ele alınmasına karşılık işin anlamlılığı ve performansın birlikte araştırıldığı bir çalışmaya rastlanmamıştır. Ancak yazında işin anlamlılığı değişkeninin bazı bileşenleri ve performans üzerine çalışmalar bulunmaktadır. Bu bağlamda Wang ve Netemeyer'in (2002) satış elemanları ile gerçekleştirdikleri araştırmada öğrenmenin öz yeterliliği, öz yeterliliğin de performansı pozitif etkilediği bulgulanmıştır. Judge ve Bono (2001) yaptıkları meta analiz sonucunda özsaygı ve iş performansı arasında pozitif ve anlamlı yönde ilişki olduğunu tespit etmişlerdir. Yine Sigler ve Pearson'ın (2000) çalışmasında, çalışanların anlamlılık algısı ile performansları arasında anlamlı bir ilişki olduğu bulgulanmıştır.

Olumlu aile yapılarının iş performansını olumlu, aksi durumun olumsuz etkilediği (Polatçı, 2011: 96) ve bireyin performans düzeyinin yeteneği, motivasyonu ve çalıştı̆̆ ortamın özelliklerinden etkilendiği ifade edilmektedir (Argon, 2010: 142). Ayrıca öz yeterliliğin, iş performansına pozitif ve anlamlı etkide bulunduğu da belirtilmektedir (Erkuş ve Günlü, 2009: 20).

\section{3. Örgütsel Sapma Davranışı}

Örgütsel sapma; bireyin içinde yer aldığı örgütün norm ve kurallarını istemli biçimde ihlal ederek örgüte, üyelerine ya da her ikisine zarar veren davranışlarıdır (Robinson ve Bennett, 1995: 556). Örgütsel sapma davranışının nedenleri; liderlik, örgüt kültürü, örgütlenme biçimi gibi örgütsel temelli, düşmanlık, kıskançlık, grup baskısı gibi sosyal grup temelli ve kişilik, yeterlilik, sosyal yetenekler gibi bireysel temelli olabilmektedir (Zapf, 1999: 71).

\section{HIIPOTEZLER}

\section{1. İşin Anlamlılığı ve İş Performansı}

Örgütlerin hedeflerini gerçekleştirmek ve rekabet avantajı kazanmak için yüksek performanslı bireylere ihtiyaç duyulduğu açıktır (Sonnentag ve Freser, 2002: 4). İşini anlamlı bulmayan ve bu nedenle ilgisiz olan bireylerden, yüksek performans beklemenin mümkün olmadığı (Çöl, 2008: 39) belirtilirken, işini anlamlı bulanların daha yüksek performans sergileyecekleri (Sigler ve Pearson, 2000: 32; Grant, 2008: 108) ifade edilmektedir. Ayrıca işe dönük özuyumu yüksek bireylerin daha iyi performans göstereceklerine (Bono ve Judge, 2003: 555) işaret edilmektedir. Bu doğrultuda aşağıdaki hipotez geliştirilmiştir:

H1: İsin anlamlılı̆̆

\section{2. İşin Anlamlılığı ve Örgütsel Sapma Davranışı}

Sapma davranışı, işin anlamlılı̆̆ına kaynaklık eden benlik, iş çevresi, iş dışı çevre, meslektaşlar, aile, ulusal kültür ve finansal koşullar ile ilişkili bir kavramdır (Bennett ve Robinson, 2003: 243-247). Bireyler örgütün norm ve değerlerine uyma ya da bağlanma davranışı göstermediğinde, örgütsel sapma davranışının oluşması için uygun bir zemin oluşmaktadır (Demir, 2009: 66). İşin anlamlılığına dair bireyin algısı güçlendikçe sapma davranışına yönelten nedenlerin ortadan kalkacağı (Zapf, 1999: 71) ifade edilmektedir. İşi benimseme düzeyi yüksek olan çalışanların örgüte yönelik yıkıcı sapma davranışlarını daha az gösterdikleri üzerinde durulmaktadır (Galperin ve Burke, 2006: 341). Bu açıklamalara istinaden aşağıdaki hipotez kurulmuştur.

H2: İşin anlamlılı̆̆l, örgütsel sapma davranışını olumsuz yönde etkiler. 


\section{H2a: İ̧sin anlamlılığı, üretime dönük sapma davranışını olumsuz yönde etkiler.}

H2b: İşin anlamlılığı, kişilerarası sapma davranışını olumsuz yönde etkiler.

\section{3. Örgütsel Sapma Davranışı ve İş Performansı}

Örgütsel sapma, örgütsel vatandaşlığın tersi olup (Motowidlo ve Kell, 2013: 92); iş performansının bir parçasıdır (Sackett, 2002; Rotundo ve Sackett, 2002; Dunlop ve Lee, 2004). Sapma davranışının, hem örgüt hem de birey temelinde üretkenlik ve performansı negatif etkilediği (Dunlop ve Lee, 2004: 70), örgüte yönelik sapma davranışının örgütsel amaçları olumsuz yönde etkilediği (Dunlop ve Lee, 2004: 70), sapma davranışlarında artışın performansta düşüşe yol açtığı (Puffer, 1987: 617) ve örgütsel sapma davranışının performansı olumsuz etkilediği (Rotundo ve Sackett, 2002: 69) bulunmuştur. Ayrıca, sapma davranışları geliştirenlerin diğer çalışanlara, hizmet alanlara olumsuz etkileri olduğu ve örgütsel hedeflerin başarılmasını da engelledikleri (Pulich ve Tourigny, 2004: 290-293, 301) belirlenmiştir. Bu aç1klamalara bağlı olarak aşağıdaki hipotez geliştirilmiştir.

H3: Örgütsel sapma davranışı, iş performansını olumsuz yönde etkiler.

H3a:Üretime dönük sapma davranışı, iş performansını olumsuz yönde etkiler.

H3b:Kişilerarası sapma davranışı, iş performansını olumsuz yönde etkiler.

\section{YÖNTEM}

\subsection{Evren ve Örneklem}

Araştırmanın evreni, herhangi bir kurumda aktif olarak çalışan bireyler olup; çalışma evreni, Mersin ilinde aktif olarak çalışan bireyler olarak tanımlanmıştır. Sosyal Güvenlik Kurumu'nun Temmuz 2016 istatistiklerinde Mersin ilinde aktif çalışan kişi sayısı 397.541 olarak raporlanmıştır (www.sgk.gov.tr).

İş performansı, araştırmanın bağımlı değişkeni olup; tepki kategorileri 5'li derecelemeye göre düzenlenmiştir. Çalışma evreni büyüklüğünün 10.000'in üzerinde olmasından dolayı örneklem büyüklüğünün hesaplanmasında ortalama için kullanılan sınırsız evren formülü kullanılmıştır. Bu derecelemede standart sapmanın, pratik bir tahminle en fazla $1^{1}(5-1=4 ; 4 / 4=1,00)$ olması öngörülmüştür (Yolal, 2016). Örnekten elde edilecek ortalamanın $\% 5$ anlam düzeyinde evren ortalamasından H: 0,10 dolayında sapma göstermesine karar

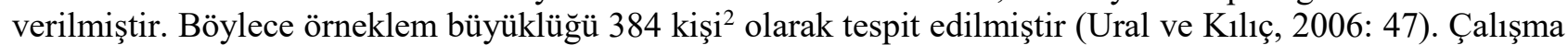
evreninin listesinin temin edilmesinin olanaksızlığ karşısında tesadüfi olmayan örnekleme tekniklerinden kolayda örneklemeye zorunlu olarak başvurulmuştur.

\subsection{Veri Toplama Aracı ve Süreci}

İlişkisel tarama modelinde tasarımlanan araştırmada veriler literatüre bağlı olarak geliştirilen bir anket ile toplanmıştır. Ankette demografik soruların yanı sıra üç de ölçek bulunmaktadır. İşin anlamlılığı, 10 maddeli Steger vd.'nin (2012) ölçeği ile belirlenmiştir. Çeviri ve tekrar çeviri süreci işletilmiştir. Tepki kategorileri 1=Kesinlikle katılmıyorum, ..., 5=Kesinlikle katılıyorum şeklinde 5'li Likert derecelemesine göre yapılmıştır. İş performansı Türkçeye Çöl (2008) tarafından çevrilen Kirkman ve Rosen (1999) ve Sigler ve Pearson (2000) kullandığı 4 maddeli ölçek ile tespit edilmiştir. Tepki kategorileri $1=$ Hiçbir zaman, $2=$ Çok nadir, $3=$ Ara sıra, 4=Çoğu zaman, 5=Her zaman şeklindedir.

Sapma davranışının belirlenmesinde, Bennett ve Robinson (2000) tarafından geliştirilen ve Yüksel (2012) tarafindan Türkçeye çevrilen 19 maddeli İşyeri Sapkınlığı Ölçeği kullanılmıştır. Uzman önerileri doğrultusunda, "İ̧ yerinde çalışmaya, hoş görülebilir süreden daha sık ve daha uzun bir şekilde mola verdiğim oldu" (Yüksel, 2012:186) maddesi, iki farklı eyleme işaret ettiği düşünülerek "Çalışmaya, amirimin tolerans göstereceği süreden daha sık mola verdiğim oldu" ve "Çalışmaya, amirimin tolerans göstereceği süreden daha uzun süre mola verdiğim oldu" ş̧eklinde ikiye bölünmüştür. Tepki kategorileri de $1=$ Hiçbir zaman, $2=$ Çok nadir, 3=Ara sıra, 4=Çoğu zaman, 5=Her zaman şeklinde 5'li derecelemeye tabi tutulmuştur.

Taslak anket, 23 Mayıs - 3 Haziran 2016 tarihleri arasında bir kamu üniversitesinin çalışanları üzerinde ön teste tabi tutulmuştur. Ön test, ankette herhangi bir değişiklik veya düzenleme yapılmasını gerektirecek bir hususun olmadığını ortaya koymuştur. Anket, bırak-topla ve yüz yüze temas teknikleri kullanılarak 15 Haziran-29 Eylül 2016 tarihleri arasında kolayda örnekleme yoluyla uygulanmıştır.

\footnotetext{
${ }^{1}$ Değişim aralığı, ölçülmeye çalışılan özelliğin aldığı en büyük değerden en küçük değerin çıkartılması ile bulunur (R: Max.-Min.). Değişim aralığının 4'e bölünmesi ile \%5 anlam düzeyindeki tahmini standart sapma elde edilmiş olur.

${ }^{2} \mathrm{n}=\sigma^{2} \cdot \mathrm{Z}^{2} \alpha / \mathrm{H}^{2}=1,96^{2} * 1^{2} / 0,10^{2}=384$ [n: Örneklem büyüklüğ̈̈; Z: Belirli anlamlılık düzeyine karşılık gelen teorik değer ( $\alpha: 0,05$ için $\mathrm{Z}$ değeri 1,96' dır), $\sigma:$ Standart sapma değeri, H: Standart hata değeri].
} 


\subsection{Verilerin Analizi}

Anket uygulama süreci sonunda 408 anket elde edilmiştir. Ölçeklerdeki kayıp veri oranının \%0,2 ile \%1,5 aralı̆̆ında olduğu tespit edilmiştir. Kayıp verilerin tesadüfen gerçekleştiği (Kalaycı, 2006: 19) tespit edildiğinden ve kayıp veri oranı \%2'yi geçmediğinden (Seçer, 2015: 17) ilgili maddenin ortalamas1, kayıp veriler yerine atanmıştır.

Kayıp verilerin tamamlanmasından sonra çok değişkenli sapan değerler, üç ölçek için ayrı ayrı olmak üzere Mahalanobis uzaklıkları (Kalayc1, 2006: 212) hesaplanarak tespit edilmiştir. İşin anlamlılığı ölçeği için 7, iş performansı ölçeğinde 2 ve sapma davranışı ölçeğinde 18 adet anketin çoklu sapan durumunda olduğu belirlenmiştir. Çakışan çoklu sapanlar da olduğundan toplam 26 gözlem, veri setinden çıkarılmıştır.

Yapılan çoklu sapan analizlerinin ardından, ölçekler yoluyla elde edilen verilerin çok değişkenli normal dağılıma uyup uymadığı kontrol edilmiştir. Bu amaçla her ölçek için küçükten büyüğe sıralı Mahalanobis uzaklıkları ile ölçekteki madde sayısını esas alan ki-kare ters değerleri arasında hesaplanan korelasyonun, madde sayısını esas alan teorik değerle karşılaştırılması yapılmaktadır. Hesaplanan korelasyonun teorik değerden büyük olması durumunda çok değişkenli normalliğin sağlandığı düşünülmektedir. (Kalayc1, 2006: 215- 216). İşin anlamlılığ için hesaplanan korelasyon $r$ : 0,967 > teorik değer: 0,860 ; iş performans1 $r: 0,953>$ teorik değer 0,813 ve sapma davranışı r: $0,947>$ teorik değer 0,912 'dir. Böylece çok değişkenli normal dağılımın sağlandığına karar verilmiştir.

Verilerin analizi birbirini izleyen beş aşamada gerçekleştirilmiştir. Öncelikle güvenirlik analizini takiben açıklayıcı faktör analizi (AFA) yapılmıştır. Ardından doğrulayıcı faktör analizi (DFA) gerçekleştirilmiştir. Elde edilen uyum iyilikleri değerlendirildikten sonra, DFA'ya bağlı olarak üç ölçeğin psikometrik özellikleri değerlendirilmiştir. Son aşamada model testi uygulanmıştır.

\section{BULGULAR}

Araştırmaya katılanların \%40’1 kadın, \%60'1 erkektir. Üçte ikisi evli olup; üçte biri bekardır. \%55'i kamu, \%45'i özel sektör çalışanıdır. Katılımcıların yaş ortalaması $\bar{x}$ : $36,05( \pm 0,45)$ yıldır. Halihazırdaki işyerlerinde ortalama çalışma yılı $\overline{\mathrm{x}}: 7,82( \pm 0,82)$ yıl olup; y1l olarak toplam tecrübe ortalama $\overline{\mathrm{x}}: 12,70( \pm 0,45)$ yıldır. Yıl olarak iş tecrübesi dikkate alındığında, verilerin doğruluğu için güçlü bir kanıt elde edilmektedir.

\section{1. Ölçeklerin Psikometrik Özellikleri}

Güvenirlik: İşin anlamlılığı, sapma davranışı ve iş performansı ölçekleri için güvenirlik analizi yapılmıştır (Tablo 1). İşin anlamlılığ ölçeğinde ters kodlama gerektiren 3.maddenin madde-toplam korelasyonu 0,081 olarak tespit edildiğinden ölçekten çıkarılmasına karar verilmiştir. 9 madde ile yapılan çözümlemede en küçük madde-toplam korelasyonu 0,514'tür. Madde-toplam korelasyonlarının minimum $+0,250$ ve üstünde olmas1 ve ayrıca negatif işaretli olmaması gerekmektedir (Kalayc1, 2006) Ölçeğin genel alfa katsayısı 0,912'dir.

Tablo 1.Ölçeklere İlişkin Güvenirlik Analizi Sonuçları

\begin{tabular}{|c|c|c|c|}
\hline Katsayılar $\quad$ Ölçekler & İşin Anlamı & $\begin{array}{c}\text { Sapma } \\
\text { Davranış1 }\end{array}$ & $\begin{array}{c}\text { İş } \\
\text { Performans1 }\end{array}$ \\
\hline Madde say1s1 & 9 & 16 & 4 \\
\hline Tüm ölçek için Alfa katsayısı & 0,912 & 0,803 & 0,811 \\
\hline Min. \& max. madde-bütün korelasyon değeri & $0,514-0,791$ & $\begin{array}{c}0,250- \\
0,506\end{array}$ & $0,565-0,686$ \\
\hline Madde-bütün korelasyonlarda negatif işaret & Yok & Yok & Yok \\
\hline Silindiğinde min. \& max.Alfa katsayısı & $0,895-0,915$ & $\begin{array}{c}0,785- \\
0,802\end{array}$ & $0,737-0,794$ \\
\hline Ortalama; standart sapma & $3,94(0,76)$ & $1,46(0,34)$ & $4,31(0,52)$ \\
\hline Tepki kategorileri & $\begin{array}{l}1=\text { K.katılmiyorum, } \\
\ldots, 5=\text { K.katıliyorum }\end{array}$ & \multicolumn{2}{|c|}{$\begin{array}{l}1=\text { Hiçbir zaman, } \\
\ldots, 5=\text { her zaman }\end{array}$} \\
\hline
\end{tabular}

Sapma davranışı ölçeğinde yer alan dört maddenin madde-toplam korelasyonları düşük olduğu (8:0,228; 10:0,170; 12:0,157 ve 20:0,226) için ölçekten çıkarılmıştır. 18 maddeli ölçek ile yapılan analizde en küçük madde-toplam korelasyonu 0,214 olarak tespit edilmiştir. Ölçeğin tamamı için alfa katsayıs 0,805 'tir. Dört maddeli iş performansı ölçeğinde en küçük madde-toplam korelasyonu 0,565 olup; alfa katsayısı 0,811'dir. 
Dolayısıyla her üç ölçekten elde edilen verilerin yüksek derecede güvenilir olduğunu (Kalayc1, 2006: 405) söylemek mümkündür.

Açıklayıcı Faktör Analizi (AFA): Ölçeklerin yapı geçerliliği için AFA yapılmıştır. AFA için en düşük eşkökenliliğin 0,500 olmasına, bir maddenin bir faktöre boyutlanması için en az 0,500 düzeyinde yüke sahip olmasına, bir faktörün en az üç maddeden oluşmasına ve varimax döndürme tekniği uygulanmasına karar verilmiştir. Binişiklik durumunda madde yükleri arasındaki farkın en az 0,100 olmasına dikkat edilmiştir (Büyüköztürk, 2015: 134- 135).

Güvenirlik analizi sonrası 9 maddeli işin anlamlılığı ölçeğine uygulanan AFA, 1.ve 10.maddenin eşkökenlilikleri 0,500'ün altında kaldığı için ölçekten çıkarılmıştır. 7 madde ile yapılan çözümlemede en küçük eşkökenlilik 0,618 ve en düşük yük 0,786 olmuş ve tek boyutlu yapı toplam varyansın \%66,286'sını açıklamıştır. KMO örneklem yeterliliği \%91,3 ve Bartlett küresellik testi $\left(\chi^{2}=1633,217 ; \mathrm{sd}=21 ; \mathrm{p}<0,001\right)$ de anlamlıdır. Böylece veri setinin faktör analizine uygunluğu ve çok değişkenli normal dağılım şartı sağlanmaktadır. Bu nedenle yedi maddenin puanları toplanarak ortalaması $(\overline{\mathrm{x}}: 3,94 ; \pm 0,81)$ alınmıştır.

Dört maddeli iş performansı ölçeğine uygulanan AFA'da; en düşük eşkökenlilik ve yük sırasıyla olmak üzere 0,554 ve 0,744 olarak gerçekleşmiştir. KMO \%79,4 olup; Bartlett için $\chi^{2}=504,562$; sd=6; $p<0,001$ 'dir. Tek boyutlu yapı; toplam varyansın \%64,363'ünü açılamıştır. Tek boyutlu yapının ortalaması $\bar{x}: 4,31$; $\pm 0,52$ 'dir.

Tablo 2. Doğrulayıcı Faktör Analizi Sonuçları

\begin{tabular}{|c|c|c|c|}
\hline BOYUTLAR & S.değerler & t-değerleri & Hata \\
\hline İŞíN ANLAMI (İA) & \multicolumn{3}{|c|}{ AVE: 0,53; CR:0,93 } \\
\hline İşimin, kişisel gelişimime katkısı olduğunu düşünüyorum. & 0,75 & 16,78 & 0,44 \\
\hline İşimin, hayatımın anlamına katkı sağladığını düşünüyorum. & 0,84 & 19,98 & 0,29 \\
\hline İşimi, neyin anlamlı kıldığının farkındayım. & 0,78 & 17,57 & 0,40 \\
\hline İşimin, çevreme olumlu bir katkı sağladığının farkındayım. & 0,74 & 16,53 & 0,45 \\
\hline İşim, kendimi daha iyi anlamamı sağlıyor. & 0,82 & 18,91 & 0,34 \\
\hline İşimin, tatmin edici bir amacı olduğunu fark ettim. & 0,78 & 17,59 & 0,40 \\
\hline İşim, çevremi ve dünyayı anlamamı sağlıyor. & 0,74 & 16,53 & 0,45 \\
\hline ÜRETIM SAPMASI (ÜS) & \multicolumn{3}{|c|}{ AVE: 0,44; CR:0,76 } \\
\hline $\begin{array}{l}\text { Çalışmaya, amirimin tolerans göstereceği süreden daha sık mola } \\
\text { verdiğim oldu. }\end{array}$ & 0,64 & 12,19 & 0,59 \\
\hline Amirimin talimatlarını yerine getirmeyi göz ardı ettiğim oldu. & 0,65 & 12,28 & 0,58 \\
\hline Kasıtlı olarak işi yavaşlattığım oldu. & 0,65 & 12,47 & 0,57 \\
\hline $\begin{array}{l}\text { Çalışmaya, amirimin tolerans göstereceği süreden daha uzun süre mola } \\
\text { verdiğim oldu. }\end{array}$ & 0,70 & 13,49 & 0,51 \\
\hline KİŞiLERARASI SAPMA (KS) & \multicolumn{3}{|c|}{ AVE: 0,44; CR:0,70 } \\
\hline Çalışanlardan birisine kırıcı sözler söylediğim oldu. & 0,65 & 11,44 & 0,58 \\
\hline Çalışanlardan birisine karşı kaba davrandığım oldu. & 0,75 & 12,97 & 0,44 \\
\hline Çalışanlardan birisini herkesin içinde mahcup ettiğim oldu. & 0,59 & 10,47 & 0,65 \\
\hline İŞ PERFORMANSI (İP) & \multicolumn{3}{|c|}{ AVE: 0,53; CR:0,82 } \\
\hline Görevlerimi zamanında tamamlarım. & 0,74 & 15,39 & 0,45 \\
\hline İş hedeflerime ulaşırım. & 0,79 & 16,91 & 0,37 \\
\hline Sunduğum hizmet kalitesinde standartlara ulaştı̆̆ıma eminim. & 0,74 & 15,38 & 0,46 \\
\hline Bir problem gündeme geldiğinde en hızlı şekilde çözüm üretirim. & 0,63 & 12,48 & 0,61 \\
\hline $\begin{array}{r}X^{2}: 303,04 \text {; d.f.: } 129 ; X^{2} / \text { d.f: } 2,35<3 \text {; RMSEA: 0,06; CFI: } 0,9 \\
\text { IFI: 0,97; RFI: 0,93; NFI: 0,94; NNFI: 0,96; RMR: 0,0 } \\
\text { Model CAIC < Doymuş CAIC: 594,74 }<1\end{array}$ & $\begin{array}{l}\text { : GFI: } 0,92 \\
8 \text {; SRMR: } 0 \\
87,679\end{array}$ & $\begin{array}{l}\text { GFI: } 0,89 \\
44 ;\end{array}$ & \\
\hline
\end{tabular}


Güvenirlik analizi sonrası 16 maddeye inen sapma davranışı ölçeği için yapılan AFA'da; dokuz maddenin eş kökenliliklerinin 0,500'ün altında kaldığı görülmüş ve analizden çıkarılmıştır. Yinelenen analiz iki boyutlu bir yapıyı teyit etmiştir. En küçük eş kökenlilik ve faktör yükü sırasıyla olmak üzere 0,525 ve 0,673 'tür. KMO $\% 73,2$ olup; Bartlett testi $\left(\chi^{2}=649,829 ; \mathrm{sd}=21 ; \mathrm{p}<0,001\right)$ de anlamlıdır. Dört maddeden oluşan üretim sapmas1 $(\overline{\mathrm{x}}: 1,52 ; \pm: 0,52)$ faktörü, toplam varyansın \%32,563'ünü açıklamaktadır. Üç maddeden meydana gelen kişilerarası sapma boyutu $(\overline{\mathrm{x}}: 3,94 ; \pm 0,81)$ ise, toplam varyansın \%27,469'unu açılamaktadır. Böylece toplam açıklanan varyans $\% 60,032$ olarak gerçekleşmiştir.

Doğrulayıcı Faktör Analizi (DFA): Her ölçeğe uygulanan açıklayıcı faktör analizinin ardından, üç ölçeği aynı anda dikkate alarak DFA yapılmıştır (Tablo 2). Modelde kullanılan değişkenlerin doğru şekilde boyutlandığı ortaya çıkmaktadır. Uyum iyilikleri dikkate alındığında $\chi^{2} /$ s.d. uyum iyiliğinin $2,35<3$ bulunduğu anlaşılmaktadır. Diğer uyum iyilikleri de incelendiğinde (RMSEA: 0,06; CFI: 0,97: GFI: 0,92; AGFI: 0,89; IFI: 0,97; RFI: 0,93; NFI: 0,94; NNFI: 0,96; RMR: 0,026; SRMR: 0,044; Model CAIC < Doymuş CAIC: $594,74<1187,679)$; modelin bir bütün olarak iyi uyum gösterdiğini söylemek mümkündür. Tüm standartlaştırılmış yüklemelerin 0,50 'den büyük olduğu ve tüm t-değerlerinin $(<1,96) \% 5$ anlamlılık düzeyinde istatistiksel olarak anlamlı olduğu da bulunmuştur.

Yakınsak Geçerlilik: Modelde kullanılan değişkenlerin ortalama varyans açıklama oranları (AVE) hesaplanmıştır. AVE değerlerinin 0,50 'den yüksek olması istenmekle birlikte, üretim ve kişilerarası sapma değişkenlerinde 0,44 olarak hesaplanmıştır. CR birleşik güvenirliğin 0,70 ' den yüksek olması durumunda bir sorun teşkil etmeyebileceği belirtilmektedir. Elde edilen model uyum istatistikleri, önemli sayılabilecek düzeyde yüklemelerin oluşması ve ikisi hariç AVE değerlerinin 0,50'den büyük olması, yakınsak geçerlik için yeterli kanıtları sağladığı yönünde bir değerlendirme (Anderson ve Gerbing, 1988; Fornell ve Larcker, 1981) yapılabilmesine olanak sağlamıştır.

Tablo 3. Ortalamalar, Standart Sapmalar ve Değişkenlerarası Korelasyonları

\begin{tabular}{|c|c|c|c|c|c|c|c|c|c|c|}
\hline & $\bar{x}$ & ss. & CR & AVE & $\begin{array}{l}\text { MS } \\
\text { V }\end{array}$ & ASV & İA & ÜS & KS & IP \\
\hline İA & 3,94 & 0,81 & 0,93 & 0,53 & 0,09 & 0,04 & $\mathbf{( 0 , 7 3 )}$ & & & \\
\hline ÜS & 1,47 & 0,50 & 0,76 & 0,44 & 0,09 & 0,07 & $-0,144^{* *}$ & $\mathbf{( 0 , 6 6 )}$ & & \\
\hline KS & 1,52 & 0,52 & 0,70 & 0,44 & 0,09 & 0,04 & $-0,110^{*}$ & $0,308^{* *}$ & $\mathbf{( 0 , 6 6 )}$ & \\
\hline İP & 4,31 & 0,52 & 0,82 & 0,53 & 0,09 & 0,06 & 0,296 & $-0,286^{* *}$ & $-0,141^{* *}$ & $\mathbf{( 0 , 7 3 )}$ \\
\hline \multicolumn{10}{|c|}{ İA: İşin anlamlılığ1; ÜS: Üretim sapmas1; KS: Kişilerarası sapma; İP: İş } \\
performans1; \\
Köşegenlerde yer alan koyu yazılmış değerler, AVE değerlerinin karekökleridir. \\
**: Korelasyon 0.01 anlam (2-yönlü) düzeyinde istatistiksel olarak anlamlıdır. \\
*: Korelasyon 0.05 anlam (2-yönlü) düzeyinde istatistiksel olarak anlamlıdır.
\end{tabular}

Ayırt Edici Geçerlik: Ayırt edici geçerlik için öncelikle maksimum paylaşılan varyanslar (MSV) ve ortalama paylaşılan varyansların (ASV) hesaplanması gerekmektedir. Ayırt edici geçerlik için ilk kontrol edilecek husus, hesaplanan AVE değerlerinin karekökünün boyutlar arasındaki korelasyondan büyük olması gerektiğidir. Tablo 3'teki verilere göre bu şartın sağlandığ 1 anlaşılmaktadır. Bir başka husus, tüm MSV değerlerinin ASV değerlerinden büyük olması, ayrıca AVE değerlerinin de MSV değerlerinden büyük olması gerektiğidir. Yapılan irdeleme ASV $<$ MSV $<$ AVE şartının karşılandığını ortaya koymaktadır. Tüm bunlar ayırt edici geçerlik için kanıt teşkil etmektedir (Hair vd., 2010).

Birleşik Güvenirlik (CR): AFA öncesinde yapılan güvenirlik analizine ilave olarak DFA sonrasında da CR katsayıları hesaplanmıştır. Tüm CR değerlerinin 0,70'ten büyük olduğu (Hair vd., 2010) tespit edildiğinden güvenirliğin bir kez daha sağlandığına dair güçlü bir kanıt elde edilmiştir.

\subsection{Model Testi}

DFA ardından model testi gerçekleştirilmiştir. Uyum değerleri üzerinde yapılan irdelemede en çok kullanılan $\chi^{2} /$ s.d. uyum iyiliğinin $2,58<3$ bulunduğu anlaşılmaktadır. Diğer uyum iyiliklerinden RMSEA, RMR ve SRMR değerleri DFA'ya göre bir miktar artsa da, bir bütün olarak değerlendirildiğinde $\left(X^{2}: 335,34\right.$; 
sd.:130; $X^{2} /$ d.f: $2,58<3$; RMSEA: 0,064; CFI: 0,96: GFI: 0,91; AGFI: 0,88; IFI: 0,96; RFI: 0,93; NFI: 0,94; NNFI: 0,95; RMR: 0,034; SRMR: 0,067; Model CAIC < Doymuş CAIC: 620,10<1187,67), modelin kabul edilebilir düzeyde olduğu ortaya çıkmaktadır. Biri hariç, modelde elde edilen tüm t-değerlerinin 1,96'dan büyük olduğu belirlenmektedir. Böylece geliştirilen biri hariç hipotezlerin eldeki veriyle desteklendiğini söylemek mümkündür (Tablo 4).

Tablo 4. Hipotez Testi Sonuçları

\begin{tabular}{|c|c|r|r|l|}
\hline$\#$ & İlişki & Katsayı & t-değeri & \multicolumn{1}{|c|}{ Sonuç } \\
\hline $\mathrm{H}_{1}$ & İA $\rightarrow$ İP & 0,29 & 4,87 & Desteklendi \\
\hline $\mathrm{H}_{2 \mathrm{a}}$ & İA $\rightarrow$ ÜS & $-0,16$ & $-2,63$ & Desteklendi \\
\hline $\mathrm{H}_{2 \mathrm{~b}}$ & İA $\rightarrow \mathrm{KS}$ & $-0,13$ & $-2,06$ & Desteklendi \\
\hline $\mathrm{H}_{3 \mathrm{a}}$ & ÜS $\rightarrow$ İP & $-0,29$ & $-4,41$ & Desteklendi \\
\hline $\mathrm{H}_{3 \mathrm{~b}}$ & KS $\rightarrow$ İP & $-0,07$ & $-1,14$ & Desteklenmedi \\
\hline$X^{2}: 335,34 ;$ sd.:130; $X^{2} /$ d.f: $2,58<3$; RMSEA: 0,064; CFI: 0,96: GFI: 0,91; \\
AGFI: 0,88; IFI: 0,96; RFI: 0,93; NFI: 0,94; NNFI: 0,95; RMR: 0,034; \\
SRMR: 0,067; Model CAIC < Doymuş CAIC: 620,10<1187,67 \\
\hline \multicolumn{4}{|c|}{ İA: İşin anlamlılı̆̆1; ÜS: Üretim sapmasi; } \\
KS: Kişilerarası sapma; İP: İş performans1
\end{tabular}

Model testinde elde edilen bulgulara göre (Tablo 4), işin anlamlılığındaki bir birimlik artış iş performansını 0,29 birim artırmaktadır. Diğer taraftan işin anlamlılığındaki bir birimlik artış, üretim sapmasını 0,16 ve kişilerarası sapmayı da 0,13 birim azaltmaktadır. Üretime dönük sapma davranışı iş performansını 0,29 birim azaltırken, kişilerarası sapma davranışının iş performansını etkilemediği belirlenmektedir.

\section{SONUÇ}

Bireyler, günlerinin neredeyse üçte birini işleri ile ilgilenerek geçirmektedirler. Dolayısıyla iş, modern yaşamın önemli bir parçası ve tartışma konusu durumundadır. Bu nedenle bireyin yaptığı işe yüklediği anlamı anlamanın ve işin anlamlılığının getirilerini tartışmanın, kritik hale geldiğinden söz etmek mümkündür. Yanı sıra işin, toplumsal bütünleşme ve yaşam amacı edinme hissi sağladığını belirten araştırma (Morse ve Weiss, 1955) bulgularının, işi anlamlı bulma düzeyine ilişkin sonuçları, durumu örgütsel perspektiften öte sosyolojik perspektife de taşıdığından söz etmek mümkündür.

\section{Kuramsal Çıkarımlar}

İşin anlamlılığının iş performansını pozitif yönde etkilediğini öne süren $\mathrm{H}_{1}$, mevcut verilerle desteklenmiştir. Dolayısıyla bireyin işini anlamlı bulma düzeyi arttıkça iş performansının artacağından söz etmek mümkündür. Bulgu, Çöl'ün (2008: 43) güçlendirme algıları ve iş performansı arasındaki ilişkiyi belirlemeyi amaçladığı çalışmasının bulgularıyla paralellik göstermektedir. İlgili çalışmada, anlam-yetkinlik boyutunun performans ile en güçlü ilişkiye sahip olan boyut olduğu ve bu boyutun performanstaki değişimin \%31'lik kısmını açıkladığı raporlanmaktadır. Yine güçlendirme perspektifinden bakıldığında Sigler ve Pearson'ın (2000: 32, 41) işini anlamlı olarak algılayan bireylerin bu algıya sahip olmayanlara göre daha yüksek performans göstereceklerine dair hipotezleri kabul görmüş ve anlamlılık algısı ile performans arasında anlamlı bir ilişki olduğu tespit edilmiştir. İşin anlamlılığının kaynakları temelinde düşünüldügünde yani teorik temelde liderliğin işin anlamlılığına katkısı olduğu göz önüne alındığında; Yılmaz ve Karahan'ın (2010: 156) liderlik davranışının performansı olumlu yönde etkilediğine dair bulgusunun da destekleyici olduğundan söz etmek mümkündür. Bu bağlamda örgütlerin işin anlamlılığını pekiştirecek iş koşullarına daha özenli yaklaşmasının bireysel performansa ve örgütsel performansa olumlu yansımaları olacağı düşünülmektedir.

İşin anlamlılığının örgütsel sapma davranışını negatif yönde etkilediğini öne süren $\mathrm{H}_{2}$ de desteklenmiştir. Bulgu; Steger vd.'nin (2012: 330) işin anlamlılığının iş tatmini, bağl1lık gibi istenen iş davranışları ile pozitif, sapma davranışları ile negatif ilişkili olduğuna dair kabul gören hipotezi ile paralellik göstermektedir. Bu doğrultuda işin ve örgütün amaçlarını bilen ve benimseyen, kişisel amaçları ile örgütsel amaçları bütünleştiren bireylerin işini daha anlamlı bulacağı ve bu amaçlara zarar verecek her türlü davranıştan kaçınacağı sonucuna ulaşılabilir. İşini anlamlı bulan bireylerin işlerine daha fazla yoğunlaşacakları ve ilgi gösterecekleri dolayısıyla sapma davranışına itibar etmeyecekleri beklenebilir.

İşin anlamlılığının üretime dönük ve kişilerarası sapmayı olumsuz yönde etkilediği ortaya çıkmaktadır. Çalışanlar, işini anlamlı bulduklarında, işe geç gelme ve mola kullanma, kasıtlı olarak işi yavaşlatma ve amirin 
talimatlarına uymama gibi örgütte resmi olarak yasaklanmış üretime dönük davranışları daha az sergilemektedirler. Aynı şekilde işin anlamlılığı arttıkça örgüt üyelerine sarf edilen kötü sözler, dedikodu, kaba davranışlar gibi kişilerarası sapma davranışı azalmaktadır.

Örgütsel sapma davranışının iş performansı üzerinde negatif yönde bir etkisi olduğuna dair $\mathrm{H}_{3}$ hipotezinin kısmi olarak desteklendiğini düşünmek mümkündür. Bunun sebebi üretime dönük sapmanın iş performansını olumsuz etkilediği iddiası destek bulurken, kişilerarası sapma davranışının istatistiksel açıdan anlamlı bir etkisinin olmamasıdır. Bu bağlamda üretim sapması arttığında iş performansının düştüğünden söz etmek mümkündür. $\mathrm{Bu}$ bulgu, alanyazında sapma davranışı ile iş performansı arasındaki ilişkiyi açıklamayı amaçlayan pek çok çalışmada (Puffer, 1987; Dunlop ve Lee, 2004; Beğenirbaş ve Çalışkan, 2014) elde edilen bulgularla paralellik göstermektedir. Ayrıca işini benimseme düzeyi yüksek olan bireylerin düşük olanlara göre daha az sapma davranışı gösterdiğine dair bulgular da söz konusudur (Galperin ve Burke, 2006: 340). Dolayısıyla iş performansını yükseltebilmek için sapma davranışının oluşma koşullarının gözden geçirilmesi ve temelde örgütsel amaçlarla bireysel amaçların bütünleştirilme faaliyetlerine önem verilmesi gerektiği düşünülmektedir.

Kişilerarası sapma davranışının ise iş performansına yansıtılmadığı ortaya çıkmaktadır. Kişilerarası davranışlar, çalışanların birbirine kırıcı sözler söylemesi, kaba davranması gibi davranışlar olup, iş performansını istatistiksel olarak anlamlı şekilde etkilememektedir ve bu anlaşılır bir durumdur. Bu, çalışanların görevini yapmak, iş hedeflerini tutturmak girişimlerini mesai arkadaşlarıyla ilişkilerinden bağımsız tuttuğunun bir göstergesidir. Böylece, iş performansının kişilerarası çatışmalardan ziyade, o işi yapanın işine yüklediği anlamdan etkilendiğine dair çağrışımlar elde edilmektedir.

\section{Uygulamaya Dönük Çıkarımlar}

İşin anlamlılığının iş performansını olumlu yönde etkilemesi, örgütlerin iş performansını arttırmak için yöneticilerin, anlamlılığın kaynakları bağlamında daha özenli çalışmalar yürütmeleri özellikle iş tasarımı, misyon, iş çevresi ve unsurlarını dikkatle gözden geçirmeleri gerektiği çağrışımlarına yol açmaktadır. İşin anlamlılı̆̆ının kaynak ve mekanizmaları temelinde uygulamacılara, işe alımlarda işin özellikleri ile bireyin kişilik ve değerleri arasındaki uyuma özen göstermeleri önerilmektedir. Wrzesniewski'de (2003) işin; acı, sıkıntı ve angarya olarak görülebileceği gibi enerji, eğlence ve memnuniyet kaynağı olarak ya da bu elementlerin hepsinin karşımı olarak görülebileceğini ifade etmektedir. Personel seçiminde sadece bilgi ölçülmemeli bireyin o işe verdiği önem, ilgi ve sevgisi de ölçülmeye çalışılmalıdır. Nitekim yaptıkları işi anlamlı bulan, işini yapmak için gerekli becerilere sahip olan, görevini nasıl yerine getireceğine karar verebilen ve işi üzerinde etkiye sahip olduğuna inanan bireylerin bu algıya sahip olmayan çalışanlardan görece daha yüksek performans düzeyine ulaşacakları ifade edilmektedir (Sigler ve Pearson, 2000: 32). Yine Grant (2008: 108) işi önemli bulmanın bireylere, işlerinde daha fazla anlamlılık deneyimlemelerini sağladığı ve bu durumun performansı arttırdığ üzerinde durmaktadır. Bu nedenle bireylerin yaptığı işi anlamlı bulması, işin çıktılarının gözlenmesi ile pekiştirilebilir. Genellikle iş çıktılarıyla ilgili olumsuz geribildirim verilirken olumlu geribildirim verilmemektedir. Oysa onay görmek, takdir edilmek Maslow'un ihtiyaçlar hiyerarşisinde yerini almaktadır. Çakıı'nın (2014) yaptığı bir çalışmada (insan kaynakları uygulamaları) performans değerlemede olumlu geribildirim yapılmamasının en önemli nedeni personeli şımartmamak olarak belirlenmiştir. Oysa iş çıktısının yararlı sonuçlanması anlam hissini geliştirebilir. Bu nedenle örgütsel iletişim güçlendirilerek ve geri bildirim mekanizması etkinleştirilerek yapılan işin diğer birey ve örgütler için önemini vurgulamanın, olumlu sonuçları beraberinde getireceği düşünülmektedir.

Liderlerin işin anlamlılığını etkileme ve şekillendirme ile ilgili önemli rolleri olduğuna dikkat çekilmektedir. Bu doğrultuda Podolny vd.'ne göre $(2005: 1,28,29)$ liderliğe bakış, anlam yaratma odağından ekonomik performansa doğru evrilmiştir. Ancak yazarlar, performans ve işi anlamlı bulmanın etkileşim içinde olduğunu vurgulamaktadırlar. Bu nedenle yöneticilerin (liderin), bireylere, örgütsel faaliyet aracılığıyla kendi ideal ve değerlerini gerçekleştirme firsatı vererek, işe anlam yükleyebileceği düşünülmektedir. Dolayısıyla liderlerin örgütün misyon, amaç ve değerlerini görünür kılarak ve bunları bireysel amaç ve değerlerle uyumlu hale getirerek işin anlamlılığına katkı sağlayacağından söz etmek mümkün görünmektedir.

Ücretlerin, işi anlamlı bulmada ve performansı artırmada etkili olduğu söylenebilir. Bireylerin işleri karşılığında aldıkları ücretin beklentilerini karşılayabilecek düzeyde ve motive edici olması gerektiği, aksi durumun performansa olumsuz etkide bulunduğu ifade edilmektedir (Saruhan ve Y1ldız, 2012: 380). Destekler biçimde bireyin performans düzeyinin yeteneği, motivasyonu ve çalıştığı ortamın özelliklerinden etkilendiği ifade edilmektedir (Argon, 2010: 142). Dolayısıyla bireysel farklılıkların göz önüne alınarak, hedef ile maddi ve manevi ödüllerin bireyselleştirilmesinin işin anlamını ve performansı pozitif etkileyebileceği söylenebilir.

Araştırmanın önemli bulgularından birisi de üretim sapması arttığında iş performansının düştüğüdür. Yöneticilerin sapma davranışının oluşma koşullarını ortadan kaldırmaya dönük önlemler alması gerektiği 
düşünülmektedir. Bu bağlamda, etik liderlik, güçlü bir örgüt kültürü yaratma, sağlıklı işleyen bir örgüt yapısı oluşturmak gibi örgütsel temelli önlemler alınmalıdır. Örgüt kültürüne ve işe uyumlu personel alımına özen gösterilmelidir. Örgüt içi gruplaşmalar, örgüt aleyhine enformel grupların etkisi, sapma davranışlarını önlemede dikkate alınmalıdır. Çünkü mesai arkadaşlarının sapma davranışlarına gösterdiği tolerans ve destek düzeyi sapma davranışını besleyebilmektedir.

Özetle, performansı arttırmak üzere uygulamacılara, çatışmalara proaktif yaklaşmak ve etkin çözüm mekanizmaları geliştirmeleri söylenebilir. Örgütsel amaçlar ile kişisel amaçları olabildiğince yüksek düzeyde uyumlu hale getirmek başka bir öneridir. Örgütsel amaçları, bunlara ulaşmada izlenecek yolları ve örgütsel değer ve prensipleri açık şekilde anlatmak da dikkate alınması gereken bir husustur. Örgütsel adaleti sağlamak; etkin iletişim mekanizmaları oluşturmak; bireysel takdir ve onay mekanizmalarını geliştirmek diğer tavsiyeler arasindadir.

\section{Akademik Öneriler}

Çalışmada ortaya konulan teorik altyapı 1şığında işin anlamlılığının, öznel iyi oluşa ve mutluluğa katkı sağlayabileceği çıkarsaması yapılabilir. Ancak bu kanı da bilimsel verilerle desteklenmeye ihtiyaç duymaktadır. Buradan hareketle işin anlamlılığı ile iş yaşamı kalitesi ve yaşam kalitesi ilişkisi de gelecekte üzerinde durulması önerilen konular arasında yer almaktadır.

Liao ve diğerlerine göre (2004: 991 - 992) meslektaş desteğinin yüksek olması yüksek düzeyde örgütsel ve kişilerarası sapma davranışı gözlenmesine neden olabilmektedir. Çünkü yüksek düzeyde meslektaş desteği algılayan çalışanlar, negatif davranışlarda bulunduklarında, meslektaşlarının bu olayı örtbas edeceğine inanmaktadırlar. $\mathrm{Bu}$ bağlamda örgüt için sapma olarak nitelendirilen davranışların, çalışanlar için böyle değerlendirilmediğinden söz edilmektedir. Dolayısıyla çalışanlarca paylaşılan davranış normları, sapmayı tolere ya da teşvik ediyorsa yüksek düzeyde meslektaş desteğinin daha fazla sapma davranışı oluşturacağı vurgulanmaktadır. Burada anlamlılık kaynaklarının daha önce sözü edilen etkisinin tersine bir durum ele alınmış olsa dahi, tek başına meslektaş etkisinden daha geniş bir perspektif işletildiğinde, yani anlamlılığın değerler, işi benimseme, misyon, kültür, maneviyat gibi boyutları birlikte düşünüldüğünde meslektaşların olumsuz etkisinden çok olumlu etkide bulunacağı düşünülmektedir. Ancak bu fikir, bilimsel araştırma bulguları ile desteklenmeye ihtiyaç duymaktadır.

Bennett ve Robinson'a göre (2003: 243-247) bireyin iş koşulları ve edindiği deneyimler, kişiliği, işyerinde benimsenen sosyal yapı ve davranış normları, meslektaşlar, gelir ve statünün dağıtımı ve ulusal kültüre dair öğeler sapmaya neden olabilmektedir. Dolayısıyla sapma davranışının, işin anlamlılığı değişkeninin kaynaklarından olan iş çevresi, iş dışı çevre, ulusal kültür ile ilişkisi araştırmayı hak eden konular arasındadır. 


\section{KAYNAKÇA}

Akgündüz, Y., Kale, A. ve Pazarbaşı, G. (2014). Futbol turizmine hizmet eden otel çalışanlarının psikolojik güçlendirme algılarının örgütsel vatandaşılı davranışlarına etkisi. Mustafa Kemal Üniversitesi Sosyal Bilimler Enstitüsü Dergisi, 11 (28), 1-15.

Anderson, J. C. ve Gerbing, D.W. (1988). Structural equation modeling in practice: A review and recommended two-step approach. Psychological Bulletin, 103 (3), 411-423. doi: 10.1037/0033-2909.103.3.411

Argon, T. (2010). Akademisyenlerin performans değerlendirme, motivasyon ve örgütsel adalet ile ilgili görüşlerine ilişkin nitel bir çalışma. International Online Journal of Educational Sciences, 2 (1), 133-180.

Arslantaş, C. C. (2008). Yöneticiye duyulan güvenin ve psikolojik güçlendirmenin örgütsel vatandaşlık davranış1 üzerindeki etkilerini belirlemeye yönelik görgül bir çalışma. TÍSK Akademi, 1, 100-117.

Bal Taştan, S. (2013). The relationship between psychological empowerment and psychological well being: The role of self-efficacy perception and social support. Öneri, 10 (40), 139-154.

Bardakçıŏlu, Ö. ve Akgündüz, Y. (2016). Otel çalışanlarının örgütsel prestij ve psikolojik güçlendirme algılarının işbirliği davranışlarına etkisi. Uluslararası Yönetim İktisat ve İşletme Dergisi, 12 (30), 145-158.

Barutçugil, İ. (2002). Performans yönetimi. İstanbul: Kariyer Yayıncılık.

Baumeister, R.F. (1991). Work, work, work, work. Meanings of Life içinde (s.116-144). NewYork: The Guilford Press.

Beğenirbaş, M. ve Çalışkan, A. (2014). Duygusal emeğin iş performansı ve işten ayrılma niyetine etkisinde kişilerarası çarpıklığın aracı rolü. Business and Economics Research Journal, 5 (2), 109-127.

Bennett, R.J. ve Robinson, S.L. (2003). The past, present, and future of workplace deviance research. İçinde Greenberg, J. (Ed.) Organizational Behavior The State of the Science (ss. 235- 268) Mahwah: Lawrence Erlbaum Associates

Bono, J.E. ve Judge, T A. (2003). Self-concordance at work: toward understanding the motivational effects of transformational leaders. The Academy of Management Journal, 46 (5), 554- 571.

Brown, S.P. (1996). A-meta-analysis and review of organizational research on job involvement. Psychological Bulletin, 120 (2), 235- 255.

Büyüköztürk, Ş. (2015). Sosyal bilimler için veri analizi el kitabı (21. Baskı). Ankara: Pegem Akademi.

Ceylan, A., Çöl, G., ve Gül, H. (2005). İşin anlamlılı̆ıııı belirleyen sosyal-yapısal özelliklerin güçlendirmeye olan etkileri ve sonuçları üzerine bir araştırma. Doğuş Üniversitesi Dergisi, 6 (1), 35-51.

Colbert, A E., Mount, M.K., Harter, J.K., Witt, L A. ve Barrick, M.R. (2004). Interactive effects os personality and perceptions of the work situation on the workplace deviance. Journal of Applied Psychology, 89 (4), 599-609. Doi: 10.1037/0021-9010.89.4.599

Çakıcı, A. (2014). Büyük Ölçekli İşletmelerde İnsan Kaynakları Uygulamaları. Düzce Üniversitesi Sosyal Bilimler Enstitüsü Dergisi, 4(1), 56-82

Çalışkan, A. ve Akkoç, İ. (2012). Girişimci ve yenilikçi davranışın iş performansına etkisinde çevresel belirsizliğin rolü. Çă̆ Üniversitesi Sosyal Bilimler Dergisi, 9 (1), 1 - 28.

Çöl, G. (2008). Algılanan güçlendirmenin işgören performansı üzerine etkileri. Doğuş Üniversitesi Dergisi, 9 (1), 35-46.

Demir, M. (2009). Konaklama işletmelerinde duygusal zeka, örgütsel sapma, çalışma yaşamı kalitesi ve işten ayrılma eğilimi arasındaki ilişkinin analizi. Yayınlanmamış doktora tezi, Dokuz Eylül Üniversitesi Sosyal Bilimler Enstitüsü, İzmir.

Demirtaş, Ö., Özdevecioğlu, M. ve Gök, K. (2015). İş-yaşam dengesinin anlamlı iş üzerindeki etkisi: Lider-üye etkileşiminin düzenleyici rolü. İçinde Karadal, H. (Ed.), 14. Ulusal İşletmecilik Kongresi, Aksaray, 550-553.

Dik, B.J., Duffy, R.D., ve Eldridge, B.M. (2009). Calling and vocation in career counseling: Recommendations for promoting meaningful work. Professional Psycology: Research and Practice, 40(6), 625-632.

Dunlop, P D. ve Lee, K. (2004). Workplace deviance, organizational citizenship behavior, and business unit performance: The bad apples do spoil the whole barrel. Journal of Organizational Behavior, 25 (1), 67-80, doi: 10.1002/job.24.

Erkuş, A. ve Günlü, E. (2009). İletişim tarzının ve sözsüz iletişim düzeyinin çalışanların iş performansına etkisi: Beş y1ldızlı otel işletmelerinde bir araştırma. Anatolia: Turizm Araştırmaları Dergisi, 20 (1), 7-24.

Fornell, C. ve Larcker, D.F. (1981). Evaluating structural equation models with unobservable variables and measurement error. Journal of Marketing Research, 18 (1), 39-50. doi: 10.2307/3151312

Galperin, B.L. ve Burke, R.J. (2006). Uncovering the relationship between workaholism and workplace destructive and constructive deviance: An exploratory study. International Journal of Human Resource Management, 17 (2), 331347, doi: 10.1080/09585190500404853

Grant, A.M. (2008). The significance of task significance: job performance effects, relational mechanisms, and boundry conditions. Journal of Applied Psychology, 93 (1), 108-124. Doi: 10.1037/0021-9010.93.1.108

Hair, J., Black, W., Babin, B. ve Anderson, R. (2010). Multivariate data analysis (7th ed.). Prentice-Hall.

Hemedoğlu, E., Koçak, M., Özkan, A., ve Berberoğlugil, B.M. (2012). Psikolojik güçlendirmenin finansal olmayan performans üzerindeki etkileri. Eskişehir Osmangazi Üniversitesi Sosyal Bilimler Dergisi, 13 (2), 87-105.

Judge, T.A. ve Bono, J.E. (2001). Relationship of core self-evaluations traits-self-esteem, generalized self-efficacy, locus of control, and emotional stability - with job satisfaction and job performance: a meta-analysis. Journal of Applied Psychology, 86 (1), 80-92. Doi: 10.1037//0021-9010.86.1.80

Kalaycı, Ş. (2006). SPSS uygulamalı çok değişkenli istatistik teknikleri. Ankara: Asil Yayın Dağıtım. 
Kirkman, B.L. ve Rosen, B. (1999). Beyond self-management: antecedents and consequences of team empowerment. The Academy of Management Journal, 42 (1), 58- 74.

Motowidlo, S.J. ve Kell, H.J. (2013). Job performance. İçinde Weiner, I. B. (Ed.) Handbook of psychology: Vol.12. (ss.82-103). New Jersey: Wiley \& Sons.

Özmutaf, N.M. (2007). Örgütlerde bireysel performans unsurları ve çatışma. C. Ü. İktisadi ve İdari Bilimler Dergisi, 8 (2), 41- 60 .

Podolny, J.M., Khurana, R. ve Hill-Popper, M. (2005). Revisiting the meaning of leadership . Research in Organizational Behavior, 26, 1-36.

Polatçı, S. (2011). Psikolojik sermayenin performans üzerindeki etkisinde iş aile yayılımı ve psikolojik iyi oluşun rolü. Yayınlanmamış doktora tezi, Erciyes Üniversitesi Sosyal Bilimler Enstitüsü, Kayseri.

Puffer, S.M. (1987). Prosocial behavior, noncompliant behavior, and work performance among commission salespeople. Journal of Applied Psychology, 72 (4), 615-621.

Pulich, M. ve Tourigny, L. (2004). Workplace deviance strategies for modifying employee behavior. The Health Care Manager, 23 (4), 290-301.

Robinson, S.L., ve Bennett, R.J. (1995). A typology of deviant workplace behaviors: A multidimensional scaling study. The Academy of Management Journal, 38 (2), 555-572.

Rosso, B.D., Dekas, K.H., ve Wrzesniewski, A. (2010). On the meaning of work: A theoretical integration and review. Research in Organizational Behavior, 30, 91-127.

Rotundo, M. ve Sackett, P. . (2002). The relative importance of task, citizenship, and counterproductive performance to global ratings of job performance: A policy-capturing approach. Journal of Applied Psychology, 87 (1), 66-80.

Sackett, P. R. (2002). The structure of counterproductive work behaviors: Dimensionality and relationships with facets of job performance. International Journal of Selection and Assessment, 10 (1/2), 5-11.

Saruhan, Ş.C. ve Yıldız, M.L. (2012). İnsan kaynakları yönetimi teori ve uygulama (1. Baskı). İstanbul: Beta Yayıncılık.

Seçer, İ. (2015). SPSS ve LISREL ile pratik veri analizi (2. Baskı). Ankara: Anı Yayıncılık.

Seligman, M.E.P. (2002). Authentic happiness: Using the new positive psychology to realize your potential for lasting fulfillment (1. Bask1). New York: Simon and Schuster.

Sigler, T.H. ve Pearson, C.M. (2000). Creating an empowering culture: examining the relationship between organizational culture and perceptions of empowerment. Journal of Quality Management, 5, 27-52.

Sonnentag, S. ve Frese, M. (2002). Performance concepts and performance theory. S. Sonnentag (Ed.). Psychological management of individual performance içinde (s. 3-25). NewYork: John Wiley \& Sons.

Sosyal Güvenlik Kurumu (2016). Mersin ili temmuz 2016 istatistikleri. 12 Ekim 2016 tarihinde http://www.sgk.gov.tr/wps/portal/sgk/tr/mersin/tumistatistik/ adresinden erişim sağlanmıştır.

Spector, P.E. ve Fox, S. (2002). An emotion-centered model of voluntary work behavior some parallels between counterproductive work behavior and organizational citizenship behavior. Human Resource Management Review, 12, 269-292.

Steger, M.F., Dik, B.J. ve Duffy, R.D. (2012). Measuring meaningful work: The work and meaning inventory (WAMI). Journal of Career Assessment, 20 (3), 322-337.

Suliman, A.M.T. (2001). Work performance: is it one thing or many things? The multidimensionality of performance in a Middle Eastern context. The International Journal of Human Resource Management, 12 (6), 1049-1061.

Wang, G. ve Netemeyer, R. (2002). The effects of job autonomy, customer demandingness, and trait competitiveness on salesperson learning, self-efficacy, and performance. Journal of the Academy of Marketing Science, 30 (3), 217 228.

Wrzesniewski, A. (2003). Finding positive meaning in work. K. S. Cameron, J. E. Dutton ve R. E. Quinn (Edt.), Positive organizational scholarship: Foundations of a new discipline içinde (s. 296-308). San Francisco, CA: BarrettKoehler.

Yelboğa, A. (2006). Kişilik özellikleri ve iş performansı arasındaki ilişkinin incelenmesi. “İş, Güç” Endüstri İlişkileri ve İnsan Kaynakları Dergisi, 8 (2), 196-211.

Yolal, M. (2016). Turizm Araştırmalarında Örnekleme, Bibliyometrik Bir Araştırma. Ankara: Detay yayıncılık.

Yüksel, S. (2012). The impact of perceptions of ethical work climates and organizational justice on workplace deviance. Yayınlanmamış yüksek lisans tezi, Orta Doğu Teknik Üniversitesi Sosyal Bilimler Enstitüsü, Ankara.

Zapf, D. (1999). Organisational, work group related and personel causes of mobbing/bullying at work. International Journal of Manpower, 20 (1/2), 70-85. Doi: 10.1108/01437729910268669. 